Niepodległość. Idee, fakty, perspektywy. W 100. rocznicę odzyskania niepodległości przez Polskę, red. P. Krokosz, S. Romański-Cebula, Kraków 2019, s. 69-100

DOI: http://dx.doi.org/Io.15633/9788374388085.05

\author{
MARIA WERONIKA KMOCH
}

Ostrołęckie Towarzystwo Naukowe im. Adama Chętnika

\title{
Wielka wojna w parafii Jednorożec (woj. mazowieckie) ${ }^{\mathrm{I}}$
}

\section{Abstrakt}

Jednorożec, największa wieś kurpiowska na zachodnim skraju dawnej Puszczy Zielonej, w I9I5 roku został całkowicie zniszczony wskutek działań wojsk rosyjskich i niemieckich. I wojna światowa to również ważna cezura w historii Kościoła w tej miejscowości - rok I9ı 6 to początek funkcjonowania osobnej parafii. Przechodzący tamtędy front rozproszył mieszkańców Jednorożca - część uciekła do okolicznych miejscowości, część udała się w bieżeństwo. Spłonął wzniesiony w I862 roku kościół, który po ustaniu działań wojennych trzeba było odbudować. Wokół nowo wzniesionej świątyni zaczęło koncentrować się życie społeczne i religijne mieszkańców. Ogromna rola Kościoła w Jednorożcu, przede wszystkim zaangażowanie miejscowych duszpasterzy w niwelowanie różnic społecznych i zażegnywanie konfliktów pomiędzy mieszkańcami (Kurpie i potomkowie szlachty) w okresie I wojny światowej i latach późniejszych, uchwytna jest we wspomnieniach spisanych przez autochtonów.

\section{Stowa kluczowe}

Jednorożec, I wojna światowa, Kościół katolicki

I Artykuł powstał jako część przygotowanej do druku monografii parafii Jednorożec. Opiera się na badaniach z lat 20I5-20I8. W latach 20I5-20I6 były one prowadzone w ramach projektu Stulecie parafii Jednorożec. Przygotowanie monografi naukowej, realizowanego dzięki stypendium starosty przasnyskiego za wybitne osiągnięcia w różnych sferach działalności edukacyjnej dla szczególnie uzdolnionych studentów zamieszkałych na terenie powiatu przasnyskiego. 


\section{Abstract}

\section{Great War in Jednorożec parish (Mazovian Province).}

Jednorożec, the greatest village in Kurpie region on the western edge of Kurpiowski Forest, became completely ruined in the result of operations of Russian and German armies in I9I5. The First World War is also the important caesura in Church history in the village - I9I 6 was the beginning of functioning of the separate parish there. The battle-front which was passing that way dispersed inhabitants of Jednorożec - some people escaped to neighbouring places, some were displaced. The church that was built in I862 burnt down; it was necessary to rebuilt the church after ceasing war-actions. Around the newly raised church social and religious life of inhabitants began to concentrate. A huge part of the Church in Jednorożec, mostly commitment of local priests in levelling of social differences and preventing conflicts among inhabitants (inhabitants of Kurpie and descendants of nobility) during the First World War and later years, are perceptible in memoirs written by autochthons.

Keywords

Jednorożec, the First World War, the Catholic Church

I wojna światowa w dziejach Kościoła w północno-mazowieckiej wsi gminnej Jednorożec (pow. przasnyski) to moment przełomowy. Z jednej strony to koniec dotychczasowej historii prężnie rozwijającej się filii (od I889 roku), z drugiej - początek funkcjonowania osobnej parafii (od ı9ı6 roku).

Druga połowa XIX wieku była czasem, kiedy determinacja i pobożność części mieszkańców parafii Chorzele ${ }^{2}$ sprawiła, że osiągnęli bardzo wiele w sferze religijnej. Parafianie z Jednorożca ${ }^{3}$ i okolic

2 Zob. R. Czarnowski, Dziedzictwo królowej Bony. Zarys dziejów parafii Chorzele, Chorzele 200I; Parafia św. Mikołaja w Chorzelach 1551-2001, oprac. M. Przytocka przy współudziale Z. Morawskiego, Ostrołęka 2003.

3 Kurpiowska wieś Jednorożec, odległa o I7 wiorst od miasta powiatowego Przasnysz, w końcu XIX wieku liczyła I I7 domów i 907 mieszkańców, posiadała 3898 mórg dobrego gruntu, I294 mórg nieużytków. Od I867 roku wieś była siedzibą gminy Jednorożec, a w latach I875-1908 sądu gminnego IV okręgu (gminy Jednorożec, Baranowo, Zaręby). Od południa wieś łączyła się z zabudowaniami wsi Stegna, dawniej należącej do dóbr Krasińskich. 
w I862 roku z własnych środków zbudowali kaplicę, zabezpieczyli uposażenie dla kapłana i wystarali się o duszpasterza posługującego w kaplicy, przekonali diecezjalne władze o konieczności utworzenia w Jednorożcu filii parafii Chorzele i założenia osobnego cmentarza. Kościół służył m.in. pomocą w działalności kulturowo-oświatowej i stał się ostoją polskości w okresie rusyfikacji ${ }^{4}$.

Niestety w I9I4 roku rozpoczęła się I wojna światowa, która dotarła do Jednorożca, położonego ok. $20 \mathrm{~km}$ od granicy z Prusami Wschodnimi, jesienią. Stefan Wilga (I9II-I994) z Jednorożca tak opisał te wydarzenia:

Przy końcu października i na początku listopada Niemcy przekroczyli granice Polski. Niemcy zajęli wioski i miasteczka ponadgraniczne i stopniowo dalsze wioski. Koło piętnastego listopada Niemcy od Chorzel doszli do Małowidza, zaczęli atakować na wieś [Ulatowo-]Pogorzel. Nasza wieś Jednorożec była przekopana okopamy parę razy w poprzek. Rosjanie szykowali silną obronę na terytorium Jednorożca i Stegny. [...] Naczęste się ścierały między sobą patrole rosyjskie i niemieckie i tak trwało do lutego do roku igI5stego. [...] W lutem Niemcy zaczęli strzelać z dział w kierunku Jednorożca, ale pociski przenosiły się za wieś i rwały się na polu. Ludzie zaczęli z wioski uciekać, ale nie wszyscy. Niedługo to trwało, może dwie godziny. [...] Ludność, która uciekła, powrócili z powrotem, nie było wypadku, żeby się spalił jakiś budynek, tylko wiatrak został uszkodzony i tak trwało do marca I9I5 roku. Mieszkańcy wioski Jednorożec przyszykowywali się do ucieczky, chowali w doły ubrania, żyto, kartofle i różne rzeczy. Koło dziesiątego marca Niemcy rozpoczęli ofensywę. Rosyjskie żołnierze zaczęli znów wyganiać ludzi, żeby cem prędzej uciekali, bo się zacznie bój. Ludność Jednorożca i Stegen wiedzieli, że to nastąpi, zaczęli opuszczać swoje zagrody. [...] Niemcy strzelali, na podwórkach mieszał się dym z kurzem, prawie się z dnia zrobiła noc. Pociski się

Stegna liczyła I8 domów, w których mieszkały I 53 osoby. Wieś dysponowała 260 morgami gruntu. W gm. Jednorożec znajdowały się: posterunek straży granicznej, urząd leśny, cztery fabryki smoły, trzy wiatraki, dwie karczmy. Zob. Jednorożec, w: Słownik geograficzny Królestwa Polskiego i innych krajów słowiańskich, red. F. Sulimierski, B. Chlebowski, W. Wawelski, t. 3, Warszawa I882, s. 55 I; Stegna, w: Słownik geograficzny Królestwa Polskiego i innych krajów słowiańskich, red. F. Sulimierski, B. Chlebowski, W. Wawelski, t. I I, Warszawa I89o, s. 319.

4 Zob. M. W. Kmoch, O pierwszym kościele w Jednorożcu i miejscowej filii parafii Chorzele (1862-1915), "Rocznik Przasnyski” (dalej: RP) 3 (2016), s. 65-I I9. 
rwały dookoła, czasami detonacja pocisków zlewała się w jeden potężny huk i trzask. Częściowo paliła się wieś Jednorożec. [...] Rosyjskie wojska wycofały się z [Ulatowa-]Pogorzeli i lasu zajęły drugą linję obrony, która była po tę stronę lasu na polach Jednorożca, a pas lasu, który ciągnął od Jednorożca do [Ulatowa-]Czerniaków był neutralny. Prawie przez środek naszej wioski przechodziła druga linja obronna. W lesie tylko zostały swadrony kozackie, na drugiej linii wojska carskie wzmocniły swoje siły na drugiej linii obronnej. Niemcy przestali strzelać z dział, zrobiło się cicho. Wieś Jednorożec była zdziesiątkowana przez niemiecką altylerję, dopalały się domy, chlewy i stodoły $[\ldots]^{\prime \prime}$.

W tym czasie interesujący nas miejscowy „Kościół stojał nie spalony”6 . O tym, jak wyglądało częściowe zniszczenie miejscowej świątyni, dowiadujemy się ze wspomnień Wilgi. Zapisał, co zobaczyli jego ojciec Tomasz i stryj Walenty. Pragnąc sprawdzić, czy Niemcy wycofali się w stronę Drążdżewa (gm. Krasnosielc), czy

zajęli okopy przy kościele [...], pojedynczo weszli do mieszkania i na górę. Z góry przez okna było wszystko widać jak na dłoni. Posiedzieli może pół godziny, wszędzie było cicho i spokojnie. Nie strzelali ani Niemcy, ani Rosjanie, nie mogli się zorientować, co dalej będzie. [...] Posiedzieli jeszcze godzinę, patrząc przez okno na kościół i na Poświątne7. Za parę minut zobaczyli Niemców wskakujących w okopy przy kościele. Ciągnęli za sobą karabiny maszynowe, wkrótce zajęli drugą linję okopów rosyjskich. Chłopy dalej obserwowali, co się dzieje na przedpolu. Nagle odezwał się Stryj: „Patrz, Tomek, Niemcy wchodzą do kościoła”. Nie trwało pół godziny, usłyszały jakyś łoskot. Zaczęli się przyglądać. Spojrzeli na kościół. Nie wierzyli swojem oczom: Niemcy zeżnęli kopułę [zapewne chodzi o wieżyczkę na sygnaturkę - M. W. K.] i zleciała na ziemię z takiem łoskotem. Chłopy dalej czekali, co z tego wyniknie, kościoła nie spuszczali z oka. Zeszło parę minut.

5 S. Wilga, Smutna Dola Wiosky Jednorożec, red. M. W. Kmoch, „Krasnosielcki Zeszyt Historyczny" (dalej: KZH) 6 (2оI6) nr I, s. 4-6.

6 S. Wilga, Smutna Dola Wiosky Jednorożec, dz.cyt., s. 9. Zob. też J. Chorzępa, Przasnysz luty 1915. „Najciekawsza bitwa I wojny światowej”, Przasnysz 2008; Z. Lorenc, I wojna światowa w gminie Jednorożec, Jednorożec 2013; R. Waleszczak, Przasnysz i powiat przasnyski w latach 1866-1939. Zarys dziejów, Przasnysz i999, s. I86-2i I.

7 Poświątne, Poświętne - część Jednorożca od Rogatek (głównego skrzyżowania we wsi, obecnie ronda) do kościoła parafialnego, obecny Plac św. Floriana (do 20 Io roku ul. Kościelna), zob. T. Wojciechowska, Jednorożec. Historia wsi, Jednorożec 20I5, s. 213. 
Z wieży kościelnej [karabin - M. W. K.] zaczął ostrzeliwać pole za Stegnamy, odezwał się drugy na Piaskach ${ }^{8}$. Wkrótce zamilkł karabin niemiecky na kościele. Z ruskych żołnierzy jeden przez zakrystję wleciał do kościoła, stanął pod kopułą i zaczął strzelać prosto do góry i zabił Niemców na wieży. Jeden z Niemców spadł na ziemię, a żołnierz rosyjski [przebiegł - M. W. K.] przez zakrystię, przeskoczył przez pargan i uciekł na Stegna. Rosjanie puścili parę pocisków altylerii na ko-

niec Piasków, gdzie szczekał niemiecki karabin maszynowy i znów ucichło?.

W celu zapewnienia sobie lepszego pola widzenia i zniszczenia punktu, w który mogliby celować Niemcy Rosjanie spalili kościóło. Nie zachował się protokół ze zniszczeń parafii, jaki władza diecezjalna kazała sporządzić w trzech egzemplarzach (dla parafii, kurii diecezjalnej i w celu przyszłego dochodzenia odszkodowań) ${ }^{\text {II }}$, który mógłby pomóc w ustaleniu czasu zniszczenia świątyni. Wedle ks. Franciszka Flaczyńskiego z Pułtuska było to „w lutym, podczas gdy toczący się w Jednorożcu bój zrównał z ziemią kościół i 240 zagród wiejskich”⒉ Odrzucić należy błędne informacje pojawiające się często w źródłach i literaturze, jakoby pierwszy kościół w Jednorożcu został zniszczony w I9I4 roku ${ }^{\mathrm{I3}}$ lub w czasie II wojny światowej ${ }^{\mathrm{I4}}$.

8 Dzisiejsza ul. Mazowiecka w Jednorożcu, zob. T. Wojciechowska, Jednorożec. Historia wsi, dz. cyt., s. 2 I 3.

9 S. Wilga, Smutna Dola Wiosky Jednorożec, dz. cyt., s. I6.

Io Archiwum parafialne w Jednorożcu (nazwa nieoficjalna, dalej: AP), Kronika ks. J. Wójcika (dalej: KKJW), s. 9 [akta nieuporządkowane, dalej: anup].

I I Rozporządzenia djecezjalne, „Miesięcznik Pasterski Płocki” (dalej: MPP) Io (I9I5) nr I I, S. 20I.

I2 F. Flaczyński, Echa przasnyskie, „Kuryer dla Wszystkich” 2 (I9I5) nr I 58, S. I.

I 3 Zob. Catalogus eccleriaium et utriusque cleri tam saecularis quam regularis Diocesis Plocensis pro Anno Dominii 1926, w: Ordo Divini Officii ad usum Dioecesis Plocensis pro Anno Domino 1926 (dalej: KD), Plociae I926, s. 55; KD I930, Plociae I930, s. 75; KD I938, Plociae I938, s. 65; Katalog duchowieństwa i parafij diecezji ptockiej (dalej: KDPDP) 1948, red. W. Jezusek, Płock I949, s. Io8; KDPDP 1955, Płock I955, s. 71; Rocznik Diecezji Płockiej 1966, Płock I966, S. I 2; Rocznik Jubileuszowy Diecezji Łomżyńskiej 2015/2016, red. T. Bronakowski i in., Łomża 20I 5, s. I23; W. Z. Łyjak, Organy na Mazowszu w diecezji płockiej od 1818 do 1925 roku, Płock 2008, s. 464; M. Pokropek, Budownictwo drewniane Kurpiów Puszczy Zielonej, Ostrołęka 2016, s. 208.

I4 Zob. Katalog zabytków sztuki w Polsce, z. I8: Przasnysz i okolice, red. I. Galicka, H. Sygietyńska, oprac. aut. I. Galicka, H. Sygietyńska, wstępną inwenta- 
W obliczu działań wojennych mieszkańcy uciekli ze wsi. Część udała się na tułaczkę z miejscowym kapłanem, ks. Józefem Ciesielskim5. Czytamy o niej w kronice parafialnej: „Ks. Proboszcz, razem ze swymi parafianami wśród zimy i mrozów tułał się w lesie państwowym koło Karolewa [gm. Krasnosielc - M. W. K.] o głodzie i chłodzie i pocieszał w różnych przygodach swoich parafian, jako dobry pasterz" ${ }^{16}$. Mieszkańcy z parafii Jednorożec zostali zakwaterowani w domach w Drążdżewie, Karolewie i sąsiednich wsiach. Tam starali się przetrzymać zawieruchę wojenną, dzieląc trudy i znoje ze swoimi dobrodziejami, którzy zgodzili się przyjąć ich do swoich mieszkañ ${ }^{17}$.

Kiedy działania wojenne nieco się uspokoiły, ks. Ciesielski wybrał się do Pułtuska do przyjaciela ks. Flaczyńskiego. Tak w liście z 8 VI I9I5 roku opisał on gościa z kurpiowskiej wsi:

Ponieważ proboszcz wyniósł z całej swojej chudoby tylko jedną starą sutannę, którą miał na sobie [...], więc przybył do Pułtuska na parę dni, by się zaopatrzyć w ubranie i bieliznę. Niechby w tym czasie zawitał w okolice Jednorożca troskliwy o nieszczęśliwych korespondent przasnyski, napisałby z pewnością, że parafianie jednoroscy pozbawieni są wszelkiej opieki ${ }^{18}$.

Latem I9I5 roku, w czasie II bitwy przasnyskiej ${ }^{\text {I9 }}$, w Jednorożcu w pobliżu kościoła przebiegała linia okopów, „które się ciągnęły przy plebanii i skręcały na Poświątne - to była trzecia linja wojska rosyj-

ryzację przeprowadziły A. Bartczakowa, F. Uniechowska, Warszawa I980, S. I3.

I5 Zob. Ks. Józef Ciesielski (1878-1944), oprac. Z. Żukowski, w: Kapłani - świadkowie wiary. Biografie wybranych księży związanych $z$ diecezją tomżyńska, red. T. Olszewski, J. Rusiecka, Łomża 20I8, s. 91-93; A. Parzych, Ks. Józef Ciesielski 1878-1944-proboszcz i dziekan ostrowski 1925-1944, „Rocznik Ostrowski” 3 (20I7), s. 240-242.

I6 AP, KKJW, s. 8 [anup].

I7 S. Wilga, Smutna Dola Wiosky Jednorożec, dz. cyt., s. 4-5.

I8 F. Flaczyński, Echa przasnyskie, dz. cyt., s. I.

I9 Zob. oprócz podanych w przypisie 6. pozycji także A. Dobroński, Walki w rejonie Przasnysza w I wojnie światowej, w: Tradycje niepodległościowe na pótnocnym Mazowszu w XIX i XX wieku. Materiaty z sesji naukowej, Przasnysz, 23 kwiecień 2003, Przasnysz 2003, s. 57-68. 
skiego"20. W samej wsi, jak i pobliskich miejscowościach, toczyły się zaciekłe walki, a w okolicy Jednorożca miało miejsce przełamanie frontu przez armię niemiecką ${ }^{21}$.

Wilga wrócił do Jednorożca dopiero w sierpniu I9I5 roku, podobnie jak inni mieszkańcy. Tak opisał widok, jaki zastała jego rodzina po powrocie z tułaczki:

Na Stegnach stojało dwa budynky, u Rzodkie[w]skiego sam zrąb przez dachu i u starego Ankula Żyda, a reszta wiosky Stegna była spalona doszczętnie. Tylko stercały kominy. Straszne to było widowisko, aż się duch lękał, dolatywał tylko smród ze spaleniska. Przy płotach było widać niepochowanych żołnierzy i spalonych w domach. Jechalim wolno, dojeżdżając do miejsca, gdzie stojał kościół i organistówka. Na miejscu, gdzie stojała organistówka, leżało dużo spalonych żołnierzy. [...] Przyszlim na Rogatky. Przy krzyzie było parę mogył. Na Piaskach stercało parę kominów po spalonych domach i [leżały - M. W. K.] ludzkie ciała posmażone od ognia”22.

Tak samo przerażający obraz zobaczył ks. dziekan Józef Piekut ${ }^{23}$, jesienią I9I5 r. objeżdżał dekanat przasnyski: "to, com widział, to są rzeczy straszne. Np. przejeżdżałem przez Jednorożec; nie mogę trafić na miejsce, gdzie stał kościół, plebania jak kościotrup tylko stoi, poszarpana, rozbita"24.

Wieś Jednorożec i kościół „ze zdrowego starodrzewu” zostały „doszczętnie spalone, jak również wsie: Nakieł i Budy Nowe [Rządowe M. W. K.]”. Przy pożarze kościoła zniszczone zostały dzwony ${ }^{25}$. Spło-

20 S. Wilga, Smutna Dola Wiosky Jednorożec, dz. cyt., s. 6.

2 I Z. Lorenc, I wojna światowa w gminie Jednorożec, dz. cyt., s. 43-66.

22 S. Wilga, Smutna Dola Wiosky Jednorożec, dz. cyt., s. 28.

23 Zob. Józef Piekut, w: A. Borkowski, Przasnyskie portrety. Część pierwsza, Przasnysz 2004, s. 98-IOI.

24 J. Piekut, Z przebytych chwil w Przasnyszu i okolicy (dokończenie), „Kurier Płocki” (dalej: KP) I (I9I5) nr I29, s. 4.

25 T. Świecki, F. Wybult, Mazowsze Płockie w czasach Wojny Światowej i powstania Państwa Polskiego, Toruń I932, s. 88; Wykaz kościołów uszkodzonych i zniszczonych oraz dzwonów kościelnych zabranych podczas I wojny światowej w diecezji płockiej-1915 r., w: Mazowsze Pótnocne w XIX-XX wieku. Materiały źródłowe 1795-1956, zebrał i przyg. J. Szczepański, Warszawa-Pułtusk I997, s. 238-239. 
nęły akta metrykalne z lat I9I4-I9I5 ${ }^{26}$. Jak informowano po latach w opisie wizytacji parafii Jednorożec, „Rosjanie [...] do spółki z Niemcami wieś całą spalili. Mieli oni, tu okopy jedni z jednej strony wsi, drudzy z drugiej a kule po wsi tak sobie spacerowały jak ludzie w odpust po cmentarzu przy kościelnym. Nic więc dziwnego, że wszystko poszło w perzynę [...]; zostało pustkowie" ${ }^{27}$.

Straty w majątku kościelnym wyniosły 8,89 tys. rubli ${ }^{28}$. Ocalały jedynie monstrancja i Pasyja ${ }^{29}$ - mosiężny neogotycki bogato zdobiony krucyfiks z przełomu XIX i XX wieku wykonany przez warsztat Plewkiewicza w Warszawie, co upamiętniono stemplem złotnika ${ }^{30}$. Krzyż zachował się do dziś.

Powroty mieszkańców Jednorożca i Stegny na ojcowiznę trwały do końca czerwca I9I6 roku³ ${ }^{31}$ W tym czasie wieś zamieszkiwało ok. 500 osób, z których większość stanowiły kobiety. „Reszta ludności rozeszła się po świecie szukać dachu nad głową"32. Nie wrócili tylko ci, którzy zostali zabrani w niewolę. Wedle listu ks. Piekuta do biskupa płockiego Antoniego Juliana Nowowiejskiego było to stu mężczyzn przetransportowanych do Prus ${ }^{33}$. Wiadomo też, że część parafian udała się w bieżeństwo34. Wilga tak wspominał początek ucieczki mieszkańców do Rosji:

26 T. Świecki, F. Wybult, Mazowsze Ptockie..., dz. cyt., s. 88.

27 Zeszłoroczna wizyta Arcypasterska sierpniowa, MPP 22 (I927) nr 5, s. I89.

28 Zniszczenia wojenne w budowlach b. Królestwa Polskiego, oprac. Z. Limanowski, Warszawa I9I8, s. 3I.

29 AP, KKJW, s. I4 [anup].

30 AP, Krzyż ottarzowy, karta sygn. OSX I60 000 289, Ośrodek Dokumentacji Zabytów w Warszawie (dalej: ODZW) I984 r., s. I [anup].

3 I S. Wilga, Smutna Dola Wiosky Jednorożec, dz. cyt., s. 3I.

32 Archiwum Kurii Diecezjalnej Łomżyńskiej (dalej: AKDŁ), Teczka osobowa: Ks. Ciesielski Józef + I944 [b.n.k.] [anup].

33 AKDŁ, Teczka osobowa: Ks. Ciesielski Józef..., dz. cyt.

34 Bieżeństwo (biał. Бежанства, ros. Беженство - uchodźstwo) - masowa ewakuacja, nazywana też wygnaniem, przesiedleniem lub wysiedleniem ludności, głównie wyznania prawosławnego, z zachodnich guberni Imperium Rosyjskiego w głąb Rosji, po przerwaniu linii frontu przez wojska niemieckie w okresie od maja do września I9I5 roku. 
Nadszedł dzień pierwszy sierpień [I9I5 roku - M. W. K.]. Z samego rana ludziom oznajmiono, żeby do trzeciego sierpnia opuścili wszyscy Krasnosielc i żeby wszyscy uciekali do Rosji. Dużo ludzi chętnie przyjęli decyzję ucieczky do Rosji. Już pierwszego sierpnia zaczęly uciekać Żydzi, gdzie jaky był Żydek, to do wieczora wszyscy uciekly. Niemało tego dnia wyjechało polskych ludzy"35.

Jan Nizielski (I907-I995) ze Stegny tak opisał ich los:

„Gdy Niemcy front rosyjski odparli na wschód, kilkanaście rodzin z Jednorożca dostało się w wir frontu rosyjskiego. Pędzeni naprzód aż za granicę rosyjską. Przebywali tam przez cały czas Rewolucji Październikowej I9I7-I9ı8 roku. Kilka rodzin nas było w Guberni Mińskiej, w centrum miasta. Reszta w różnych miejscowościach Rosji, aż w pobliżu Wołgi”.

W grupie bieżeńców znaleźli się m.in. Nizielscy, Piotr Jachimowski, Walenty Opalach oraz bracia Gładkowie z trzema synami ${ }^{36}$. Poza tym w bieżeństwo z omawianego terenu ruszyli: Atanazy Żebrowski (Jednorożec), Teodor Świdziński z żoną (Jednorożec), Franciszka Tubis z rezydentem (prawdopodobnie rodzicem) i dwójką dzieci (Stegna), Wiktoria Lisiecka (Budy Rządowe), Marcin Mydło z żoną i dzieckiem (Nakieł) i Wiktor Lisiecki (Budy Rządowe). Trafili do guberni: kałuskiej, twerskiej, jarosławskiej i riazańskiej37.

Po przejściu frontu do Jednorożca „Wrócił i ks. Proboszcz Ciesielski, a kiedy nie zastał kościoła i budynków parafialnych zamieszkał we wsi Ulatowo Pogorzel. [...] Nabożeństwo odprawiał w domu Piotraka Franciszka” ${ }^{8}$. Ks. Piekut zapisał, że kapłan „tam urządził sobie kapliczkę. Żywot pędzi prawie bezczynny. Biblioteka jego została zniszczona czytać przeto niema co - prasy parafialnej bardzo niewiele. On sądzi, że tę parafię można by przyłączyć do Parciaków lub Drążdżewy. Sam zaś pragnął otrzymać inną parafię", był bowiem podłamany świado-

35 S. Wilga, Smutna Dola Wiosky Jednorożec, dz. cyt., s. 2 I.

36 T. Wojciechowska, Jednorożec. Historia wsi, dz. cyt., s. 57-58.

37 Archiwum Akt Nowych w Warszawie (dalej: AAN), Centralny Komitet Obywatelski Królestwa Polskiego [w Piotrogrodzie] [I9I4] I9I5-I9I8, sygn. 385, k. 2-3. Są to jedynie niektóre nazwiska bieżeńców z parafii Jednorożec. Zagadnienie to nie będzie rozwijane, bowiem wymaga dalszych badań.

38 AP, KKJW, s. 9 [anup]. 
mością, że młodsi od niego kapłani zostali przeniesieni do innych placówek, on zaś musi przebywać w Ulatowie-Pogorzeli „lubo zniszczony i zdenerwowany strasznie. Sądzę, że nie o materialne względy tu mu chodzi [...]. Lecz jego osobista duma została podrażniona. Wszak on jest doktorem filozofii, pracuje już kilka lat w Jednorożcu z pożytkiem [od ı9ı roku - M. W. K.]”. Dziekan przasnyski popierał prośbę ks. Ciesielskiego o przeniesienie do innej placówki, bowiem taka decyzja „go podtrzyma na tej bezludnej, spalonej, zniszczonej i rowami strzeleckim porzniętej parafji Jednorożskiej. Był bowiem bardzo spokojny - niósł pomoc materialną biedakom, a teraz zaczyna się zniechęcać" 39 . Rzeczywiście, jak informuje kronika parafialna, ks. Ciesielski „nie mógł przeboleć tego ucisku swej parafii i poprosił władze kościelne o inną parafię"40. Opuścił Jednorożec w listopadzie I9I5 roku, przenosząc się do Lubiela ${ }^{41}$. Do lata następnego roku wierni pozostawali bez duszpasterza.

Życie w zniszczonym Jednorożcu i okolicy było bardzo trudne. Parafianie mieszkali w piwnicach zniszczonych domów, w murowanych parskach oraz w szałasach ${ }^{42}$.

Wszędzie na podwórzach rosły pokrzywy, jak zagajnik. Tylko robactwo się lęgło, jaszczurki różnego koloru, a nawet trafiały się i żmije. Ludzie z głodu odkopywali kopce ze zgniłemy kartoflamy. Suszyli zgniłe kartofle na słońcu, robili z nich mąkię, gotowali i jedli. Nawet komosę i drobne pokrzywy - wszystko ludzie zgotowaly i zjedli. A kto miał jakiegoś konia, to pojechał do sąsiednich wiosek, kupił kartofli i jakąś ćwiartkię żyta, to zmielono ją w żarnach i gotowaly rżaną kaszę. [...] Rzadko się zdarzało, żeby kto upiekł chleb, bo jak chto kupił żyta, to musiał je wsypać w kartofle, żeby przewieźć do domu, bo Niemcy jak zobaczyli żyto, to zaraz zabrali. [...] Gdzieśkolwiek trafiło się parę kłosów z samosiewu³.

Żywiono się też rybami złapanymi w Orzycu. W późniejszym czasie głównym pożywieniem były brukiew, marchew i ziemniaki. Wypiek

\footnotetext{
39 AKDŁ, Teczka osobowa: Ks. Ciesielski Józef..., dz. cyt.

40 AP, KKJW, s. 9 [anup].

4I Zmianyw składzie osobistym duchowieństwa djecezjalnego, MPP Io (I9I5) nr I2, s. 256.

42 Z. Lorenc, I wojna światowa w gminie Jednorożec, dz. cyt., s. 38.

43 S. Wilga, Smutna Dola Wiosky Jednorożec, dz. cyt., s. 3 I-32.
} 
chleba utrudniało rekwirowanie ziarna przez Niemców. Urządzali oni też łapanki np. na ulicach Przasnysza i wywozili ludność na roboty do Niemiec ${ }^{44}$.

Przyjęło się, że w I9ı6 roku biskup Antoni Julian Nowowiejski erygował w Jednorożcu osobną parafię. Brak jednak informacji o powstaniu nowej jednostki np. w „Miesięczniku Pasterskim Płockim”, organie prasowym diecezji. Brakuje wzmianek w lokalnej prasie katolickiej (np. „Mazur”) i świeckiej („Głos Płocki”, „Kurier Płocki” itp.). Ciekawe jest też, że pierwszy schematyzm (katalog diecezjalny), wydany po erygowaniu parafii, a pochodzący z I9ı8 roku, nadal określa Jednorożec jako filię sui iuris parafii Chorzele, a w późniejszych, aż do lat 6o. XX wieku, nie podaje się daty erygowania parafii. Dopiero schematyzm płocki z roku Ig66 datuje ją "ok. I9ı6” roku. Zapewne dlatego, że wówczas proboszczem parafii Jednorożec był ks. Józef Wójcik45. To on nadesłał odpowiednie informacje do wydawców schematyzmu, odpowiadając na apel dotyczący prowadzenia kronik parafialnych i spisywania dziejów wspólnot parafialnych ${ }^{46}$. W ślad za tym w dotychczas wydanych opracowaniach podaje się I9ı6 rok jako moment erygowania parafii.

Czy możliwe jest, że w Jednorożcu powołano parafię w czasie I wojny światowej, choć nie ma żadnych źródeł to potwierdzających? By odpowiedzieć na to pytanie, trzeba wspomnieć, że w tym okresie w prasie katolickiej diecezji płockiej, na terenie której całkowicie zniszczony został co dziesiąty kościół ${ }^{47}$, miała miejsce szeroko zakrojona akcja dotycząca budowy nowych świątyń albo (częściej) odbudowy po zniszczeniach wojennych. Radzono, z jakich materiałów i w jakiej formie najlepiej jest budować kościoły. Akcja związana była z ogólnokrajową dyskusją o warunkach i kształcie odbudowy drewnianej architektury,

44 Z. Lorenc, I wojna światowa w gminie Jednorożec, dz. cyt., s. 72-73.

45 Interesował się przeszłością parafii, o czym świadczy założenie kroniki parafialnej oraz korespondencja z poprzednimi proboszczami i notatki przechowywane w archiwum parafialnym.

46 W. Jezusek, Kronika parafialna, MPP 43 [44] (I959) nr I-2, s. 26-28.

47 M. M. Grzybowski, Kościół katolicki, w: Dzieje Mazowsza, t. 4: Lata 1918-1939, red. J. Szczepański, Pułtusk 20Io, s. 607. 
również kościelnej ${ }^{4}$. W „Miesięczniku Pasterskim Płockim” opublikowano orędzie biskupa płockiego Nowowiejskiego, dotyczące poważnej „bolączki” diecezji - zbytniego oddalenia wsi od kościołów parafialnych i potrzeby powołania nowych jednostek. Pasterz diecezji zachęcał, by wierni zastanowili się i naradzili, gdzie potrzebne są zmiany przynależności wsi do parafii. Upoważnił księży dziekanów w diecezjach do składania odpowiednich podań w Kurii Biskupiej. List pasterski w tej sprawie wydano na początku marca I9I6 roku49. Na łamach czasopisma rozwinęła się też dyskusja, w której wskazywano, że jeśli regulowaniem granic ma kierować „wzgląd na sprawę Bożą i dobro moralne ludu", to nie tylko trzeba przydzielać odległe wsie do najbliższych kościołów, ale inicjować też „tworzenie nowych parafji, lub co najmniej filii”. Dodawano też: „Setki lat już minęły od czasu utworzenia większości naszych parafii, a przez te setki lat dużo się także zmieniło". Jako przykład potrzeby powiększenia liczby parafii w diecezji podawano sytuację Kurpiów. Lud ten „swoją zabiegliwością, wytrwałością i jednomyślnością przyczynił się do powstania około dziesiątka parafii lub filji” ${ }^{5}$.

Można się domyślać, że po odczytaniu pisma diecezjanie zrealizowali apel biskupa. W Jednorożcu sprawa była trudniejsza - wówczas wieś i okolice nie miały własnego duszpasterza, nie było też kościoła. Kto miał odczytać rozporządzenia biskupa? Wierni z okolic mogli je usłyszeć jedynie w Chorzelach. Jednak raczej nie udawali się tam do kościoła z powodu jego zniszczenia ${ }^{5 \mathrm{i}} \mathrm{i}$ konieczności odbudowy wła-

48 G. Ruszczyk, Drewniane kościoły w Polsce 1918-1939. Tradycja i nowoczesność, Warszawa 2001, s. 95-96.

49 List pasterski ks. bp A. J. Nowowiejskiego z 9 III 1916 r., MPP I I (I9I6) nr 3, s. 68-7I.

50 [...ski], Stówko w kwestii rozgraniczenia parafji, MPP I I (I9I6) nr I, s. 30-33.

5 I We wrześniu I9I4 roku ostrzał artyleryjski uszkodził naroże kościoła w Chorzelach, fragment cokołu i ścianę frontową. Dach i drzwi przedziurawiły karabiny i granaty. Następnie w kościele urządzono skład owsa. Parafii udostępniono prawą nawę. W marcu I9I5 roku Niemcy wysadzili wieżę kościelną, przy okazji niszcząc ścianę frontową, chór i nawy. Remont kościoła rozpoczął proboszcz ks. F. Olszewicz, a od I9I8 roku kontynuował ks. A. Krysiak. Zob. Parafia św. Mikołaja..., dz. cyt., s. 30. 
snych domostw. To miejscowy dziekan, czyli ks. Piekut z Przasnysza, musiał zająć się tą sprawą.

Na pewno władza diecezjalna dowiedziała się o całkowitym zniszczeniu Jednorożca i miejscowej świątyni, ponieważ prowadzono statystykę zniszczeń ${ }^{52}$. Może też jakaś grupa parafian udała się do Płocka z prośbą o powołanie nowej parafii. Ciekawej obserwacji na temat uporu Kurpiów w załatwianiu spraw parafii u władz diecezji dokonał ziemianin Eugeniusz Kłoczowski (I897-I985) z Bogdan Wielkich (gm. Chorzele) ${ }^{53}$, opisując przykładowe działanie mające na celu zmianę proboszcza:

Kurpie nie pisali do biskupa ze skargą, tylko posyłali tam delegację. Nabrała ona w koszyki chleba i sera i szła I5o wiorst do Płocka. Biskup ją przyjął i jak zwykle oświadczał, że sprawa musi być zbadana, że musi rozmawiać i z księdzem, i z dziekanem. Bardzo dobrze - mówiła delegacja - „muma czas, poczekuma”. Zasiadali na stopniach arcybiskupiego pałacu i cierpliwie siedzieli, póki zirytowana kuria nie pozbyła się ich zapowiedzią [rozwiązania sprawy - M. W. K.]. Wtedy odchodzili, ale jakby decyzja się odwlekała, znów się zjawiali - cierpliwi, ale jak mur nieustępliwi ${ }^{54}$.

Konkretniejszych informacji na temat trybu erygowania parafii dostarcza Rozporzadzenie w sprawach: konieczności i zachowywania przepisów obowiązujących budowniczych kościotów i przestrzegania formalności przy zmianach granic parafii, wydane 9 czerwca I9I6 roku przez biskupa płockiego. Jeśli do dziekana wpłynęła prośba o utworzenie nowej parafii, to zobowiązany był sprawdzić, czy prośba mieszkańców była wiarygodna, słuszna i racjonalna, sprawdzić autentyczność podpisów i określić liczbę osób posiadających prawa publiczne oraz tych, którzy chcą powołania nowej parafii. Następnie dziekan spisywał protokół, do którego dołączał własną opinię na temat prośby miesz-

52 Statystyka strat wojennych w djecezji Płockiej, MPP I I (I9I6) nr 3, s. 88-89; Z okolic zniszczonych, KP I (I9I5) nr IO4, S. 2.

53 Zob. A. Borkowski, Eugeniusz Józef Dominik Kłoczowski, w: A. Borkowski, P. Kaszubowski, Przasnyskie portrety. Część druga, Przasnysz-Ciechanów 2008, S. $44-46$.

54 E. Kłoczowski, Wspomnienia mazowieckiego ziemianina $z$ lat 1897-1951, red. A. K. F. Wołosz, Ciechanów 2006, s. I I4. 
kańców, i wysyłał wszystkie dokumenty do Płocka. Biskup, po rozpatrzeniu prośby mieszkańców i pozytywnej opinii dziekana, wydawał rozporządzenie erygujące nową parafię i określał datę rozpoczęcia jej działalności55.

Powołując nową parafię, wyznaczano jej duszpasterza, co uczyniono I9 czerwca I916 roku. Wówczas „wikariuszem parafii Jednorożec” został ks. Konstanty Lewandowski ${ }^{6}{ }^{6}$ (wraz z czasowym zarządem parafii Brodowe Łąki) $)^{57}$. Początkowo ks. Lewandowski „przez pewien czas zamieszkiwał w parafii Brodowe Łąki, bo w Jednorożcu nie było gdzie mieszkać"58. Do wsi przybył, kiedy zaczęła grasować tu grypa hiszpanka, by „zaopatrzyć ludzi umierających w sakramenta święte na ostatnią drogę" 59. Mogło się to stać po czerwcu igı6 roku, bowiem przygotowane w lipcu tego roku sprawozdanie Rady Opiekuńczej Powiatu Przasnyskiego za czerwiec nie podaje istnienia Miejscowej Rady Opiekuńczej w parafii Jednorożec, której przewodniczącym był ks. Lewandowski. Do jej wydzielenia mogło dojść dopiero po przybyciu kapłana do Jednorożca ${ }^{60}$.

Tak zapamiętał ks. Lewandowskiego pięcioletni wówczas Wilga:

Był to człowiek młody, o wzroście średnim, jakieś metr siedemdziesiąt centymetrów, włosy ciemny blond, oczy łagodne i miłe. [...] Ludzie się cieszyli, że mają

55 Rozporządzenia w sprawach: konieczności zachowania przepisów obowiązujących budowniczych kościotów i przestrzegania formalności przy zmianach granic parafii, w: Listy z Tumskiego Wzgórza, t. 2: Pozostate Listy Pasterskie oraz Orędzia, Dekrety $i$ Zarzadzenia, a także fragmenty korespondencji Bt. Abp. Antoniego Juliana Nowowiejskiego $z$ lat 1909-1940, zebrał ks. T. Żebrowski, red. W. Banasiak, ks. H. Seweryniak, Płock 2008, s. 72.

56 Zob. Konstanty Lewandowski 1886-1943, w: M. M. Grzybowski, Duchowieństwo diecezji płockiej, Wiek XX, t. I, cz. I, Płock 2007, s. 3 I 3-3 I4; Lewandowski Konstanty ks., w: S. Pajka, Stownik biograficzny Kurpiowszczyzny XX wieku, Kadzidło 2008, s. 588-589.

57 Zmiany w sktadzie osobistym duchowieństwa diecezjalnego, MPP I I (I9I6) nr 7, S. $22 \mathrm{I}$.

58 AP, KKJW, s. I2 [anup].

59 S. Wilga, Smutna Dola Wiosky Jednorożec, dz. cyt., s. 30.

Go AAN, Rada Główna Opiekuńcza w Warszawie (dalej: RGO) I9I5-I920 [I92 II922], sygn. 658, s. 80, I06, I09. 
swojego proboszcza. Pokochali swojego proboszcza, a proboszcz pokochał swoich parafijanów. Suknię na sobie miał parcianą i podarte buty. Żył i mieszkał razem z mieszkańcamy naszej wiosky. Mszę odprawiał w mieszkaniu Marcina Piotraka, u syna starego Piotraka ${ }^{6 \mathrm{I}}$.

Problemu nastręcza status kapłana. Skoro został mianowany wikariuszem, to oznacza, że tak naprawdę był zatrudniony w Chorzelach, a w Jednorożcu pełnił posługę na tych samych zasadach, co dotychczasowi duszpasterze. Nie ma rozporządzenia, wydanego później, które by zmieniało jego status na proboszczowski. Możliwe więc, że początkowo ks. Lewandowski był administratorem, a nie proboszczem parafii Jednorożec. Jak wynika ze sprawozdania ze stanu parafii po II wojnie światowej, dokument erekcyjny parafii Jednorożec potwierdzający jej powstanie, spisany został dopiero w 1922 roku $^{62}$, ale zaginą $\mathfrak{r}^{63}$ lub co bardziej prawdopodobne - spłonął w czasie działań wojennych. W archiwach nie odnaleziono żadnego odpisu ani kopii dokumentu. Z drugiej jednak strony należy zauważyć, że określenie „dokument erekcyjny" przy roku 1922 pojawia się dopiero w protokole tradycyjnym z I949 roku. Wcześniej, w I924 i I929 roku, określenie „dokument z I922 roku" zapisano tuż za wymienieniem odpustów parafialnych ${ }^{64}$, więc prawdopodobne, że data ta odnosiła się do indultu odpustowego, a nie aktu erekcji parafii.

Informacja o odwołaniu z Jednorożca poprzednika ks. Lewandowskiego - ks. Ciesielskiego - zawiera sformułowanie „zarządzający parafią Jednorożec" ${ }^{5}$, sugerujące, jakby już w I9I5 roku istniała tu osobna jednostka kościelna. Było to związane ze statusem sui iuris, jaki Jednorożec posiadał od I9o 6 roku $^{66}$, ale nie równało się istnieniu tu osobnej parafii.

6I S. Wilga, Smutna Dola Wiosky Jednorożec, dz. cyt., s. 32.

62 AP, Kuria Biskupia. Akta parafii Jednorożec od r. I9I2 - do r. I958 (dalej: KBAPJ), Protokół tradycyjny (dalej: PT), I924 r., s. 2 [anup].

63 Ibidem, PT, I945 r., s. 4 [anup].

64 Ibidem, PT, I924 r., s. 2 [anup]; PT, I929 r., s. I [anup].

${ }_{5}$ Zmiany w składzie osobistym duchowieństwa djecezjalnego, MPP Io (I9I5) nr I2, S. 256.

66 AP, KKJW, s. 5 [anup]. 
Podsumowując, skoro pasterz diecezji skierował ks. Lewandowskiego do Jednorożca z dniem Ig czerwca I9I 6 roku, można podejrzewać, że wówczas powstała parafia Jednorożec. Prawdopodobnie rozpoczęła ona funkcjonowanie od I stycznia I9I7 roku, o czym świadczą zapisy w księgach metrykalnych. Już kolejnego dnia spisano pierwsze metryki zgonów, informujące o śmierci parafian w okresie wojny. Pierwszy bieżący akt spisano I9 stycznia i dotyczył on zgonu z poprzedniego dnia - zmarł ośmiomiesięczny Józef Suchwicki z Jednorożca ${ }^{67}$.

Długoletnie starania mieszkańców, by odłączyć się od parafii Chorzele i posiadać własną jednostkę kościelną, wreszcie zostały zwieńczone sukcesem. Parafia otrzymała wezwanie św. Floriana i wydaje się, że było to spowodowane pragnieniem, aby święty czuwał nad tym, by nigdy więcej mieszkańcy nie doświadczyli tak wielkiego pożaru, jaki strawił okolicę w I9I5 roku. Może też miał bronić wiernych przed wojną ${ }^{68}$. W granicach nowej parafii, wydzielonej z obszaru parafii Chorzele i Krasnosielc ${ }^{6}$, znalazły się następujące wsie: Budziska, Budy Rządowe, Jednorożec, Kobylaki-Wólka, Nakieł, Stegna, Ulatowo-Czerniaki, Ulatowo-Pogorzel, Ulatowo-Słabogóra. W I9I7 roku parafia liczyła 2065 mieszkańcówº.

Odbudowę zniszczonej przez działania wojenne świątyni planowano tuż po nieszczęściu, choć początkowo zapewne w formie tymczasowej kaplicy. Między lutym (I bitwa przasnyska i zniszczenie kościoła

67 Archiwum Urzędu Stanu Cywilnego w Jednorożcu, Akta zmarłych, 8/I9I7.

68 Św. Florian (ur. w II poł. III wieku) służył w armii cesarza rzymskiego Dioklecjana, którego rządy charakteryzuje prześladowanie chrześcijan. Ujął się za prześladowanymi towarzyszami, za co został skazany na karę śmierci. Zginął 4 maja 304 roku w nurtach rzeki Enns na terenie dzisiejszej Austrii.

69 Zob. M. M. Grzybowski, Jubileusz 6oo-lecia parafii Krasnosielc 1386-1986, „Studia Płockie" I 5 (I987), s. 203-214; A. A. Pszczółkowski, Miasteczka szlacheckie w ziemi ciechanowskiej, w: Działalność społeczno-gospodarcza mazowieckich ziemian w okresie od XVIII do XX wieku, red. B. Umińska, Ciechanów 20I4, s. 36-40; A. A. Pszczółkowski, Źródła do dziejów parafii (Krasno) Sielc. XVIXVII wiek, KZH I (2010) nr 2, s. 7-9.

70 Directorium seu Ordo Divini Officii (...) ad usum Dioeceseos Plocensis, Płock I9I7, s. 47 . 
w Jednorożcu) a listopadem I9I5 roku (przeniesienie ks. Ciesielskiego do Lubiela) należy datować list ks. Piekuta, w którym dziekan przasnyski informował biskupa o rozmowie z kapłanem posługującym w Jednorożcu. Ten „oświadczył, że o budowie kaplicy w Jednorożcu w obecnych warunkach mowy być niemoże, potrojne rowy strzeleckie przeszywają tę wieś"ౌı. Sprawę odłożono w czasie.

Dopiero gdy do Jednorożca przybył ks. Lewandowski, który okazał się być aktywnym społecznikiem, rozpoczęły się przygotowania do budowy nowego kościoła ${ }^{72}$. Pojawiła się myśl, by postawić świątynię w innym miejscu, niż stała przed I wojną światową. Pomysł wyszedł od mieszkańców wsi Ulatowo-Pogorzel, którzy pragnęli wystawić kościół tam, gdzie kiedyś podobno istniał niewielki klasztor73. Kapłan postanowił osobiście obejrzeć proponowane miejsce, „lecz kiedy wyszło na jaw, że ziemia która kiedyś należała do klasztoru przeszła na własność kilku gospodarzy, to ksiądz zrezygnował z budowy tam kościoła”. Podjęto decyzję, że kościół stanie w miejscu poprzedniego74, czyli na niewielkim pagórku na skraju wsi Jednorożec, w pobliżu cieku wodnego oddzielającego go od wsi Stegna.

7I AKDŁ, Teczka osobowa: Ks. Ciesielski Józef..., dz. cyt.

72 Zeszłoroczna wizyta Arcypasterska sierpniowa, MPP 22 (I927) nr 5, s. I89.

73 W XVII wieku właściciele Ulatowa-Pogorzeli, wzorem polskiej szlachty, zapisali część swoich dóbr parafii chorzelskiej. Według opowieści mieszkańców klasztor w Ulatowie-Pogorzeli miał być zbudowany podczas najazdu szwedzkiego. Istniała tu kaplica, którą w I725 roku opiekowali się członkowie zakonu św. Franciszka Serafickiego. Kwitł tu kult św. Stanisława BM. W I78I roku zapisano, że całość majątku weszło w posesję WWOO bernardynów z Przasnysza. W I783 roku część wsi należała do przasnyskich bernardynów, a inna do bernardynek. W I864 roku na mocy zarządzeń carskich nastąpiła kasata zakonów. Majątek zakonny i wszelkie zapisy w bankach przeszły na skarb państwa. Zob. Archiwum Diecezjalne w Płocku, Acta Visitationis, sygn. 254, k. 20; sygn. 262, k. 372; sygn. 303, k. I45; AP, KKJW, s. I 3 [anup]; „Regestr diecezjów” Franciszka Czaykowskiego, czyli właściciele ziemscy w Koronie 1783-1784, do druku podał S. Górzyński, przypisami i wstępem opatrzyli K. Chłapowski, S. Górzyński, Warszawa 2009, s. 464; T. Wojciechowska, Ulatowo-Pogorzel, w: Zapiski Ziemi Jednorożeckiej, red. M. Dworniczak i in., Jednorożec 20I I, s. 56.

74 AP, KKJW, s. I3 [anup]. 
Należało otrzymać zgodę władz diecezjalnych na budowę świątyni. Ks. Lewandowski rozpoczął starania o kupno drzewa, które można było przeznaczyć na budowę kościoła i zabudowań parafialnych. Jako że przemysł leśny kontrolowali okupujący ten teren Niemcy, którzy masowo wycinali lasy i za pomocą wybudowanej w igI5 roku kolejki wąskotorowej wywozili drewno do Prus ${ }^{75}$, „[...] po [...] staraniach u władz niemieckich ksiądz otrzymał przydział drzewa"76 z okolic Karolewa77. Kronika parafialna sugeruje, że ks. Lewandowski musiał bardzo usilnie prosić Niemców o pozwolenie na przydział drewna, zaś Wilga twierdzi, że Niemcy „dali przedział przez pieniędzy. Kazali, żeby zeżnąć, to oni odbiorą". Nie czekając długo, kapłan odwiedził wszystkie domy i parski, prosząc, by następnego dnia mieszkańcy stawili się do wycinki lasu za Stegną.

Wierni ochoczo zabrali się do pracy, chociaż zajęci byli odbudową własnych domów. „Ludzie postawione budynky pokrywali trawą, zwaną rzeżuchą, która rosła na łąkach i nad rzeką. Słomy nie było, bo pola wiosky Jednorożec stanowiły jedną pustynię. Skopane okopamy, splątane drutami kolczastymy i zryte pociskamy artyleryjskymy, zasłane trupamy ludzkiemy i końskiemu"78. Mieszkańcy zatrudniali się przy budowie niemieckiej kolejki wąskotorowej. Dzięki temu mogli wykorzystać drewno z lasów do odbudowy własnych zabudowań. Inni zbierali trupy i chowali je na licznych cmentarzach wojennych, co było koniecznie nie tylko z powodu jak najszybszego przygotowania pól pod uprawę, ale też ze względów sanitarnych. Ciała poległych żołnierzy, znajdujące się w pobliżu ujęć wody, mogły wywołać epidemię79. Pozostali mieszkańcy szukali drutów kolczastych na polach zrytych okopami, a potem przekazywali Niemcom, za co otrzymywali drobną zapłatę ${ }^{80}$.

75 Zob. M. W. Kmoch, Wielka Wojna we wspótczesnym krajobrazie gminy Jednorożec (pow. przasnyski), „Akademickie Zeszyty Naukowe Piast” I (20I7), s. 25-28;

A. Tajchert, Koleje waskotorowe na Kurpiach, Rybnik 20I5, s. 7.

76 AP, KKJW, s. I3 [anup].

77 A. Drwęcki, Ruch oporu w gminie Jednorożec 1939-1945, Jednorożec 20I I, s. 8.

78 S. Wilga, Smutna Dola Wiosky Jednorożec, dz. cyt., s. 32.

79 Z. Lorenc, I wojna światowa w gminie Jednorożec, dz. cyt., s. 3I.

80 S. Wilga, Smutna Dola Wiosky Jednorożec, dz. cyt., s. 30. 
Ludność Jednorożca pracowała o głodzie i chłodzie, przy swojej budowie i przy robocie niemieckiej. Ludzie naszej wiosky rozchodzili się jak mrówky za żywnością. Piechotą i konno do Krasnego [i - M. W. K.] pod Mławę, bo w bliskich wioskach nie można było kupić ani kartofli, ani żyta. [...] w naszej wiosce było [...] krów może piętnaście sztuk i wszystkie stare. Co było młode, wszystko poszło do kuchni wojskowej. Wojsko zjadło bydło, a wojna strawiła wszystko, całe mienie mieszkańców wiosky Jednorożec. Pomimo głodu i niedostatku wieś Jednorożec zaczęła powstawać z martwych. [...] Powstawały domy większe i mniejsze. Powstawały szopky mieszkalne i pojedyncze mieszkania razem z chlewem. [...] Mieszkańcy wiosky Jednorożec, kochając swoje Ojczyznę, nie szczędzili trudu i wysiłku. Od pracy i głodu wszyscy wyglądaly jak szkielety $^{81}$.

Wilga opisał też dokładnie, jak wyglądało przygotowanie drewna do budowy kościoła w Jednorożcu:

Pierwszego dnia pojechało parę wozów i proboszcz z nimy. Zajechaly do Boru. Niemiecky leśniczy już [tam - M. W. K.] był. Pokazał, w którem miejscu mają zżynać drzewo. Proboszcz i leśniczy odeszli na stronę. Pogadali parę minut. Ksiądz poprosił go, żeby kazał zabrać drzewo zaraz na fury, żeby nie jechać pustemu wozamy do domu. W leśniczym się okazało polskie serce w niemieckim mundurze, powiedział: „Bierzcie, wiele wam potrzeba, a co zostanie, to ja odbierę. A jutro to przyjdą robotnicy z nadleśnictwa, to będą zżynać dla Niemców drzewo, to ja parę sztuk odbierę do kościoła, bo jak przeprowadzą kolejkię, to drzewo oprze się w Prusach”. Na odchodzie leśniczy podał rękię proboszczowi i powiedział: „Ja jestem Polakiem, nie bójcie się niczego” - powiedział. „Do widzenia!” - i odszedł do Lypy. Ksiądz przyszedł do mojego Ojca i powiedział wszystko, jakie warunki przekazał mu leśniczy, zagiął suknie do góry i powiedział: „My z Broncią będziemy zżynać drzewo, a wy z Aleksandrem obcinajcie $\mathrm{z}$ gałęzi, to furmani będą mieli gotowe na fury. Zaraz będą mogli chłopy kłaść na wozy. Po co mają konie stoić. Furmani pojadą z drzewem do wiosky, a my będziemy zżynać do wieczora”. I tak się stało. Chłopy pokładli drzewo na wozy ${ }^{82}$.

Chociaż we wsi „koni było bardzo mało, ale drzewo zwieziono szybko, [...] ażeby jak najprędzej sprowadzić drewno i pobudować kościół ${ }^{83}$.

8I S. Wilga, Smutna Dola Wiosky Jednorożec, dz. cyt., s. 30.

82 S. Wilga, Smutna Dola Wiosky Jednorożec, dz. cyt., s. 32.

83 AP, KKJW, s. I3 [anup]. 
Chociaż Powiatowa Rada Opiekuńcza w Przasnyszu (PROP) ${ }^{84}$ prowadziła Biuro Porad Budowlanych, których udzielał architekt Konrad Korecki, za opłatą zaś przygotowywał plany odbudowy budynków, nie skorzystano z jego pomocy. Biuro powstało w czerwcu I9I6 roku, czyli przed rozpoczęciem budowy świątyni w Jednorożcu ${ }^{85}$. Zniszczonych działaniami wojennymi drewnianych kościołów nie objęły również starania Towarzystwa Opieki nad Zabytkami Przeszłości, którego oddział w Przasnyszu powstał w I9ı6 roku. Chociaż w odezwie oddziału pisano, że „przecież świątynie nasze to niemal zawsze wartościowe zabytki budownictwa rdzennie polskiego"86, koncentrowano się na murowanych starych świątyniach, np. kościele w Czernicach Borowych oraz klasztorze pobernardyńskim w Przasnyszu $^{87}$. Może zabrakło funduszy, bowiem plany były szersze („Koło Przasnyskie [...] ma zamiar również przyjść z pomocą w odbudowaniu [...] innych zabytków w okolicy, dla braku funduszów jednak akcji tej rozwinąć nie jest w możności" ${ }^{88}$ ). Nie wiadomo nic o wsparciu finansowym udzielonym jednorożeckiemu kapłanowi przez PROP, a takowe wystosowano np. dla parafii Pawłowo Kościelne, również zniszczonej w I9I5 roku $^{89}$, ale posiadającej zabytkowy murowany kościół9o. Warto dopowiedzieć, że PROP planowała zorganizować spółkę wyrobu materiałów dla całego powiatu, której zadaniem miała być produkcja materiałów budowlanych i sprzedaż ich po cenach produkcji, a niejednokrotnie pomoc bezinteresowna, co mogłoby wydatnie wspomóc budowę kościoła w Jednorożcu. Problemem było jednak nastawienie władz okupacyjnych, które przewidywały taki

84 Zob. M. W. Kmoch, Między idea a rzeczywistością. Rady Opiekuńcze na przykładzie powiatu przasnyskiego (1916-1918), „Bieżuńskie Zeszyty Historyczne” 32 (2018), s. 64-II6..

85 AAN, RGO, sygn. 426 [b.n.k.]; sygn. 658, s. 84 .

86 AGAD, Szef Administracji przy Generał-Gubernatorstwie Warszawskim (dalej: SAGGW), sygn. o9०, k. I-2.

87 AAN, RGO, sygn. 658, s. 84, I I8; A. Pęski, Ziemia Przasnyska, KP 2 (I9ı6) nr 67, s. 3 .

88 AGAD, SAGGW, sygn. o9o, k. 2.

89 Wykaz kościołów uszkodzonych..., dz. cyt., s. 238.

90 AAN, RGO, sygn. 658, s. 89. 
zakład jedynie dla Przasnysza. Rada dążyła do tego, by kierownictwo spółki zostało w polskich rękach, o co zabiegano w RGO9. Planów nie zrealizowano.

Ks. Lewandowski, młody, ale z doświadczeniem pięcioletniego wikariatu w Długosiodle, był nie tylko sprawnym organizatorem, ale i pracowitym człowiekiem:

Ksiądz się poniewierał pomiędzy ludziamy jak prosty chłop. Po Mszy co dzień jechał do Boru wybierać drzewo i z leśniczem zaraz odbierali i bily nomera. To trwało około trzech dni. Chłopy z całej parafji wozili przez przerwy. Parafianie wzięli się do roboty z proboszczem na czele. Ludzie z całej parafji co dzień zgłaszali się do roboty, proste ludzie i fachowcy: stolarze, murarze, tracze. Ze stolarzy zgłosił się stolarz Czaplicky, Graczyk i Obrębsky Stanisław, a nasz proboszcz zbierał wieczorem furmanky po drzewo. Chodził do wszystkich, co mieli konie i prosił: „Pomózcie my, drodzy parafianie”. Z furmanamy sam jeździł wieczorem do Boru i pomagał kłaść drzewo na fury. Starał się ponad siły. Ludzie polubili proboszcza. Pomagali jak mogli, czynem i materialnie ${ }^{92}$.

Ks. Konstanty bowiem już od najmłodszych lat odznaczał się fizyczną siłą i pracowitością, co predestynowało go do pracy w kurpiowskich parafiach, gdzie wierni „cenili i szanowali tych ojców duchownych, którzy mocno stąpali po ziemi, «sielnie» gospodarowali i imponowali siłą fizyczną w stopniu nieprzeciętnym" ${ }^{93}$.

Decyzję o miejscu złożenia gotowego drewna ks. Lewandowski pozostawił Walentemu Ferencowi (I889-I957), który był projektantem i głównym budowniczym kościoła. Drewno obrobił w swoim tartaku w Stegnie Żyd M. Rajchert (Rychert) „za pół ceny, no przecie parafija jest biedna"94. Gdy tylko odbudowano tartak po jego niewielkich wojennych zniszczeniach ${ }^{95}$, przygotowanie desek do budowy kościoła było pierwszym zleceniem dla właściciela. Tartak pracował na parę wodną, był opalany trocinami i drewnem. Dzięki niemu zarówno

9I AAN, RGO, sygn. 658, s. 84 .

92 S. Wilga, Smutna Dola Wiosky Jednorożec, dz. cyt., s. 33.

93 Konstanty Lewandowski 1886-1943 ..., dz. cyt., s. 31 3.

94 S. Wilga, Smutna Dola Wiosky Jednorożec, dz. cyt., s. 33.

95 T. Świecki, F. Wybult, Mazowsze Płockie..., dz. cyt., s. 9I. Tartak w Stegnie funkcjonuje w spisie jako fabryka. 
budowa kościoła, jak i odbudowa wsi mogły postępować szybciej ${ }^{6}$. Przed wojną pracowało tu szesnaście osób97, możliwe, że po I9I5 roku podobnie.

W tych trudnych warunkach mieszkańcy przekazywali datki na budowę kościoła, a podobne ofiary napływały też spoza parafii. Przykładowo w połowie ı9ı6 roku w „Miesięczniku Pasterskim Płockim” informowano, że „kapłan emeryt z diecezji Chełmińskiej ofiarował I0०० marek na odbudowanie kościoła w Jednorożcu"98.

Najpierw postawiono dom parafialny (dla pracowników kościelnych, tzw. organistówka), w którym w październiku I9I6 roku zamieszkali ks. Lewandowski i organista. Zbudowany ze środków pochodzących z dobrowolnych ofiar parafian kościół był gotowy w czerwcu I9I7 roku (podobnie jak plebania) ${ }^{99}$, a nie w I9I8 roku, jak dotychczas podawano w literaturze przedmiotu. Wynikało to albo z nieuważnego odczyta-

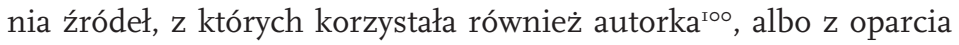
się na kronice autorstwa ks. Wójcika zamiast na przechowywanych w archiwum parafialnym w Jednorożcu protokołach z przekazania parafii kolejnym duszpasterzom ${ }^{\text {Ior }}$. Do I979 roku we wszystkich takich dokumentach podawano rok i9I7 jako czas budowy kościoła ${ }^{\text {102 }}$, dopiero w protokole sporządzonym przy przekazywaniu parafii następcy ks. Wójcicka, ks. Janowi Krynickiemu, ten pierwszy błędnie podał datę I9I8 roku, którą później powtarzano zarówno w protokołach tradycyjnych ${ }^{\mathrm{I0}}$, jak i opracowaniach popularnonaukowych ${ }^{\mathrm{I04}}$, a nawet

96 T. Wojciechowska, Jednorożec. Historia wsi, dz. cyt., s. 68.

97 R. Waleszczak, Przasnysz i powiat przasnyski..., dz. cyt., s. I33.

98 Odpowiedzi i Informacje, MPP I I (I9I6) nr 8, s. 249.

99 S. Wilga, Smutna Dola Wiosky Jednorożec, dz. cyt., s. 33.

Ioo Z. Lorenc, I wojna światowa w gminie Jednorożec, dz. cyt., s. 73.

IoI T. Wojciechowska, Jednorożec. Historia wsi, dz. cyt., s. 68, I92.

I02 Zob. AP, KBAPJ, PT, I945 r., s. 3 [anup]; PT, I953 r., s. I [anup].

I03 Zob. Archiwum Kurii Diecezjalnej Płockiej (dalej: AKDP), Akta parafii Jednorożec I949-I99I (dalej: APJ), PT, I979 r., s. I [anup]; PT, I983 r., s. I [anup]; PT, I99I r., s. I [anup].

I04 Zob. M. Pokropek, Budownictwo drewniane..., dz. cyt., s. 208; G. Ruszczyk, Drewniane kościoły..., dz. cyt., s. 230; T. Wojciechowska, Jednorożec. Historia wsi, dz. cyt., s. 68, I92. 


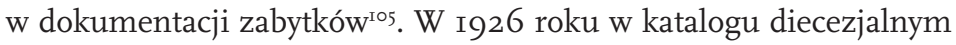
podano błędną datę budowy kościoła ${ }^{\mathrm{ro}}$, którą powtarzano później we wszystkich schematyzmach płockich ${ }^{107}$ i łomżyńskich ${ }^{108}$. Możliwe jednak, że rok I9I8, co znaleźć można w wielu opracowaniach, oznacza benedykcję kościoła. Został poświęcony przez ks. Piekuta, ale w źródłach nie podano, kiedy ${ }^{\mathrm{10}}$.

Jak pierwotnie wyglądało wyposażenie świątyni w Jednorożcu? Ołtarz główny pochodził z drugiej połowy XIX wieku i był przerobiony z ikonostasu, sprowadzonego z rozebranej w I9ı8 roku cerkwi pw. Narodzenia NMP w Przasnyszu ${ }^{\text {II }}$. Ustawiono go jednak dopiero ok. I922 roku ${ }^{\text {III }}$ „ „Kiedy już wszystkie budowle były doprowadzone

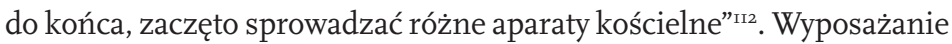
i upiększanie kościoła oraz jego otoczenia trwało przez całe dwudziestolecie międzywojenne.

W obliczu ogromnych zniszczeń regionu konieczne było stworzenie instytucji dobroczynno-pomocowych, które zajęłyby się potrzebującymi mieszkańcami. Na początku ı9ı6 roku powstała wspomniana już PROP, podzielona na sekcje, odpowiadające za różne zadania. Przewodniczącym Zarządu był Stanisław Żórawski, ziemianin z Obrębca. Działalność Rady koncentrowała się na wieloaspektowej pomocy ludności potrzebującej, która przejawiała się m.in. udzielaniem kredytów na zakup zboża i ziemniaków, zakupami artykułów żywnościowych dla przytułków, ochronek i bezpłatnych jadłodajni czy rozdawnictwem zapomóg pieniężnych dla najuboższych. Wyceniano też straty wo-

I05 Zob. AP, Karta ewidencyjna zabytków architektury i budownictwa nr 22: Kościót parafialny p.w. Narodzenia Najświętszej Marii Panny, ODZW I984 r., [anup]; Katalog zabytków sztuki..., dz. cyt., s. I 3; Zabytki architektury i budownictwa w Polsce, z. I5: Województwo warszawskie, oprac. O. Puciata, Warszawa I972, s. 33.

Io6 Zob. KD, I926, s. 55 .

I07 Zob. KD, I930, s. 75; KD, I938, s. 65; KDPDP 1948, s. Iо8; KDPDP 1955, s. 7I; Rocznik Diecezji Płockiej 1966, dz. cyt., s. I I2.

Io8 Zob. Rocznik Jubileuszowy Diecezji Łomżyńskiej..., dz. cyt., s. I23.

IO9 AP, KBAPJ, PT, I924 r., s. 2 [anup].

I IO Katalog zabytków sztuki..., dz. cyt., s. I3.

I I I AP, Ottarz główny, karta nr 9I, ODZW, I984 [anup].

I 2 AP, KKJW, s. I 3 [anup]. 
jenne, urządzano kwesty na rzecz potrzebujących dzieci, m.in. akcję „Ratujmy dzieci”.

Ks. Lewandowski włączył się w pomoc potrzebującym jako Przewodniczący Miejscowej Rady Opiekuńczej (MRO) parafii Jednorożec. Wcześniej pomoc organizowano wedle gmin, a na terenie gminy Jednorożec opiekunem gminnym był ks. Walenty Mroczkowski, proboszcz z sąsiedniej parafii Parciaki. Dodatkowo ks. Lewandowski, jako delegat parafii Jednorożec, pracował w strukturach powiatowych Rady. Członkami MRO parafii Jednorożec byli Adam Matłoch i Tomasz Deptuła ${ }^{\mathrm{II}}$.

MRO w Jednorożcu wydawała zapomogi dla potrzebujących, żywność, odzież itp. Do września I9I6 roku prowadzono w gminie jedną ochronkę („w Parciakach dla Jednorożca, który przez wojnę spalo-

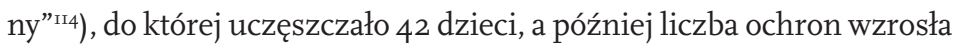
do trzech (Parciaki, Lipa, Żelazna), gromadząc ıog dzieci, także z sąsiednich miejscowości. Wedle sprawozdań PROP kurpiowscy mieszkańcy powiatu, w tym ludność parafii Jednorożec, bardzo doceniali otrzyma-

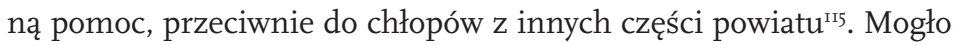
to być związane z tym, że w czasie wojny „najwięcej ucierpiały wsie zamieszkałe przez Kurpiów (w Jednorożcu - 2000 ludności - zniszczona, w. Lipa 40 gospodarstwa zniszczone, w. Szla - całkowicie)"II6.

W czasie okupacji niemieckiej mieszkańcy od ı9ı6 roku odbudowywali zniszczony Jednorożec i okoliczne wsie, ale nie zapomnieli o walce. Na terenie gmin powstawały placówki i sekcje, zaś w miastach plutony i kompanie Polskiej Organizacji Wojskowej (POW). Ta tajna organizacja wojskowa powstała w sierpniu I9I4 roku w Warszawie w wyniku połączenia konspiracyjnego Związku Walki Czynnej i grup Armii Polskiej. Jej celem była walka z zaborcą. Placówki POW miały swoje kryptonimy, a żołnierze posługiwali się pseudonimami ${ }^{117}$.

I 3 Zob. M. W. Kmoch, Między ideą a rzeczywistością..., dz. cyt., s. 78.

I 4 A. Pęski, Ziemia Przasnyska, KP 2 (I9I6) nr 67, s. 3.

I 5 AAN, RGO, sygn. 658, s. 56.

II6 AAN, RGO, sygn. 426 [b.n.k.].

I I7 A. Drwęcki, Działalność Polskiej Organizacji Wojskowej w powiecie przasnyskim w latach 1916-1918, „Zeszyty Naukowe Ostrołęckiego Towarzystwa Naukowego" 3 (I989), s. I7. 
Również w Jednorożcu powstała sekcja POW, do której należeli: Franciszek Berk, Dębski, Stanisław Kardaś, Władysław Mordwa, Jan Sobieraj, Antoni Wilga, Stanisław Łukasiak, Władysław Frączak, Walenty Wilga, Józef Wilga i prawdopodobnie Marceli Połomski. Członkiem i kapelanem jednorożeckiej POW miał być ks. Lewandowski ${ }^{\text {I8 }}$. Miejscowy oddział POW brał udział w rozbrojeniu Niemców w dniach IO-I2 września I9I8 roku ${ }^{\text {II9 }}$.

W I9I6 roku lokalne oddziały Polskiej Macierzy Szkolnej (PMS) reaktywowano dzięki przychylnej polityce niemieckiego okupanta. Przewodniczącym koła w Jednorożcu został ks. Lewandowski. Po po-

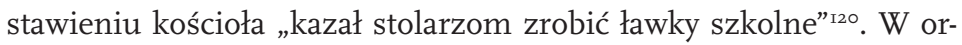
ganistówce, którą zajmował, zorganizował w jednym pokoju szkołę i sprowadził do wsi nauczycielkę Lucynę Pupik (I899-I920), kuzynkę $e^{\text {I2I }}$ lub córkę przyjaciół. Od roku szkolnego I9I7/igI8 szkolnictwo przekazano pod polski zarząd, co pozwoliło na utworzenie trzech nowych szkół, mieszczących się w izbach w prywatnych chłopskich mieszkaniach. Uczyło się tu łącznie I47 uczniów ${ }^{\mathrm{I22}}$. Według sprawozdania złożonego na spotkaniu przasnyskiego oddziału PMS w końcu I9I7 lub początku I9I8 roku, w Jednorożcu w ramach działań Macierzy, ze względu na trudne warunki i brak lokalu organizowano jedynie amatorskie przedstawienia teatralne i prenumerowano "Gazetę Świąteczną” ${ }^{23}$. Pomimo tego, jak zapisał Wilga, „W naszem Jednorożcu zakwitło życie, jak w maju kwiaty. Pomiędzy ludnością zakwiłło życie kulturalne i duchowe. Ludność Jednorożca żyła w strasznej przyjaźni. Życzliwi byli jeden dla drugego. Nie było samolubstwa i kłamstwa. Co niedziela się zbieraly mieszkańcy naszej wioski jak żurawie na jesieni

I 8 Z. Cierliński, Na pótnoc od Przasnysza: Baranowo, Chorzele, Jednorożec, Przasnysz I996, s. I6; A. Drwęcki, Działalność Polskiej Organizacji Wojskowej..., dz. cyt., s. 9.

I I9 S. Wilga, Smutna Dola Wiosky Jednorożec, dz. cyt., s. 34-37; A. Drwęcki, Dziatalność Polskiej Organizacji Wojskowej..., dz. cyt., s. I9-23.

I20 S. Wilga, Smutna Dola Wiosky Jednorożec, dz. cyt., s. 33.

I2 I Ibidem; A. Drwęcki, Działalność Polskiej Organizacji Wojskowej..., dz. cyt., s. 8.

I22 T. Wojciechowska, Jednorożec. Historia wsi, dz. cyt., s. 68.

I23 T. Świecki, F. Wybult, Mazowsze Płockie..., dz. cyt., s. I67. 
i radzili pomiędzy sobą, jak zapobiec biedzie i komu pomóc w budowie jakiego szałasu, żeby go wyciągnąć na wierzch z parsku, albo coś pomóc w polu" ${ }^{22}$.

Wojna polsko-bolszewicka w I920 roku na krótko zawitała w okolice Jednorożca ${ }^{\text {I25}}$, ale poza tym epizodem okres międzywojenny był dość spokojny. Pomimo biedy i trudów życia codziennego parafianie z Jednorożca angażowali się w wyposażenie zbudowanego przez siebie kościoła oraz działalność organizacji społecznych ${ }^{\mathrm{I2} 6}$.

Choć z powodu wielu braków źródłowych, śmierci świadków historii oraz braku bezpośrednich relacji okres ten jest trudny do odtworzenia, warto pochylić się nad zagadnieniem organizacji parafii w okresie I wojny światowej. Na przykładzie kurpiowskiej parafii Jednorożec można wskazać na zjawiska charakterystyczne dla naszego kraju w okresie wielkiej wojny. Mamy tu bowiem i charakterystykę działań wojennych na froncie wschodnim, i problemy dnia codziennego polskiej wsi, działalność organizacji samopomocowych, samoorganizowanie się mieszkańców, walkę niepodległościową i inne, a wszystko opisane m.in. w kronice parafialnej oraz zapiskach mieszkańca Stefana Wilgi. Co więcej, do dzisiaj pamięta się o przełomowości tego okresu dla lokalnej historii, czego wyrazem jest m.in. statuetka Jednorożca dla ks. Lewandowskiego, przyznana w grudniu 2017 roku za „wkład pracy oraz odbudowę życia na płaszczyźnie religijnej i społecznej mieszkańców miejscowości i gminy Jednorożec na początku XX wieku, a także aktywność w dążeniu do niepodległości Państwa Polskiego" ${ }^{\text {I27 }}$ czy wreszcie przygotowana do druku monografia parafii Jednorożec pióra autorki artykułu.

I24 S. Wilga, Smutna Dola Wiosky Jednorożec, dz. cyt., s. 33.

I25 T. Wojciechowska, Jednorożec. Historia wsi, dz. cyt., s. 73-74.

I26 Zob. M. W. Kmoch, Organizacje religijno-społeczne w parafii Jednorożec w okresie międzүwojennym, RP 5 (2018), s. 25-70.

I27 E. Bonalska, Statuetka Jednorożca 2017 dla księdza, „Głos Gminy Jednorożec” (20I8) nr I (49), s. 7 . 


\section{BIBLIOGRAFIA}

I. ŹRÓDłA ARCHIWALNE

I.I. ARCHIWUM AKT NOWYCH W WARSZAWIE:

Centralny Komitet Obywatelski Królestwa Polskiego [w Piotrogrodzie] [I9I4] I9I5-I9I8, sygn. 385 .

Rada Główna Opiekuńcza w Warszawie, sygn. 426.

Rada Główna Opiekuńcza w Warszawie, sygn. 658.

I.2. ARCHIWUM DIECEZJALNE W PŁOCKU:

Acta Visitationis, sygn. 254.

Acta Visitationis, sygn. 262.

Acta Visitationis, sygn. 303.

I.3. ARCHIWUM G£ÓWNE AKT DAWNYCH W WARSZAWIE:

Szef Administracji przy Generał-Gubernatorstwie Warszawskim, sygn. ○९॰.

\section{I.4. ARCHIWUM KURII DIECEZJALNEJ ŁOMŻYŃSKIEJ:}

Teczka osobowa: Ks. Ciesielski Józef + I944 [akta nieuporządkowane].

\section{I.5. ARCHIWUM PARAFIALNE W JEDNOROŻCU [NAZWA NIEOFICJALNA]:}

Karta ewidencyjna zabytków architektury i budownictwa nr 22: Kościót parafialny p.w. Narodzenia Najświętszej Marii Panny, Ośrodek Dokumentacji Zabytów w Warszawie, ı984 r. [akta nieuporządkowane].

Kronika ks. J. Wójcika [akta nieuporządkowane].

Kuria Biskupia. Akta parafii Jednorożec od r. I9I2 - do r. I958 [akta nieuporządkowane.

Krzyż ottarzowy, karta sygn. OSX I60 ooo 289, Ośrodek Dokumentacji Zabytów w Warszawie, ı984 r. [akta nieuporządkowane]. 
Ołtarz główny, karta nr 9I, Ośrodek Dokumentacji Zabytów w Warszawie, ıو84 r [akta nieuporządkowane].

\section{I.6. ARCHIWUM URZĘDU STANU CYWILNEGO W JEDNOROŻCU:}

Akta zmarłych I9I7.

\section{2. ŹRÓDÆA DRUKOWANE}

Catalogus eccleriaium et utriusque cleri tam saecularis quam regularis Diocesis Plocensis pro Anno Dominii 1926, w: Ordo Divini Officii ad usum Dioecesis Plocensis pro Anno Domino 1926, Plociae I926.

Catalogus eccleriaium et utriusque cleri tam saecularis quam regularis Diocesis Plocensis pro Anno Dominii 1930, w: Ordo Divini Officii ad usum Dioecesis Plocensis pro Anno Domino 1930, Plociae I930.

Catalogus eccleriaium et utriusque cleri tam saecularis quam regularis Diocesis Plocensis pro Anno Dominii 1938, w: Ordo Divini Officii ad usum Dioecesis Plocensis pro Anno Domino 1938, Plociae I938.

Directorium seu Ordo Divini Officii [...] ad usum Dioeceseos Plocensis, Płock I9I7. Jezusek,W., Kronika parafialna, „Miesięcznik Pasterski Płocki” 43 [44] (I959) nr I-2, s. 26-28.

Katalog duchowieństwa i parafij diecezji płockiej 1948, red. W. Jezusek, Płock I949.

Katalog duchowieństwa i parafij Diecezji Płockiej 1955, red. W. Jezusek, Płock I955.

Kłoczowski E., Wspomnienia mazowieckiego ziemianina z lat 1897-1951, red. A. K. F. Wołosz, Ciechanów 2006.

List pasterski ks. bp A. J. Nowowiejskiego z 9 III 1916 r., „Miesięcznik Pasterski Płocki” II (I9ı6) nr 3, s. 68-7i.

Odpowiedzi i Informacje, „Miesięcznik Pasterski Płocki” II (І9ı6) nr 8, s. 249. 
"Regestr diecezjów” Franciszka Czaykowskiego, czyli właściciele ziemscy w Koronie 1783-1784, do druku podał S. Górzyński, przypisami i wstępem opatrzyli K. Chłapowski, S. Górzyński, Warszawa 2009.

Rocznik Diecezji Płockiej 1966, Płock I966.

Rocznik Jubileuszowy Diecezji Łomżyńskiej 2015/2016, red. T. Bronakowski $\mathrm{i}$ in., Łomża 20I5.

Rozporządzenia djecezjalne, „Miesięcznik Pasterski Płocki” Io (I9I5) nr II, S. 201 .

Rozporządzenia w sprawach: konieczności zachowania przepisów obowiązujących budowniczych kościołów i przestrzegania formalności przy zmianach granic parafii, w: Listy z Tumskiego Wzgórza, t. 2: Pozostate Listy Pasterskie oraz Orędzia, Dekrety i Zarządzenia, a także fragmenty korespondencji Bt. Abp. Antoniego Juliana Nowowiejskiego z lat 1909-1940, zebrał ks. T. Żebrowski, red. W. Banasiak, ks. H. Seweryniak, Płock 2008, s. 72-73.

Rozporządzenia djecezjalne, „Miesięcznik Pasterski Płocki” Io (I9I5) nr II, S. 201 .

Statystyka strat wojennych w djecezji Płockiej, „Miesięcznik Pasterski Płocki” II (I9I6) nr 3, s. 88-89.

Wilga S., Smutna Dola Wiosky Jednorożec, red. M. W. Kmoch, „Krasnosielcki Zeszyt Historyczny" 6 (2016) nr I (27), s. 3-44.

Wykaz kościołów uszkodzonych i zniszczonych oraz dzwonów kościelnych zabranych podczas I wojny światowej w diecezji płockiej - 1915 r., w: Mazowsze Pótnocne w XIX-XX wieku. Materiaty źródtowe 1795-1956, zebrał i przyg. J. Szczepański, Warszawa-Pułtusk I997, s. 238-239.

Zeszłoroczna wizyta Arcypasterska sierpniowa, „Miesięcznik Pasterski Płocki” 22 (I927) nr 5, s. I89.

Zmiany w składzie osobistym duchowieństwa djecezjalnego, „Miesięcznik Pasterski Płocki” Io (I9I5) nr I2, s. 256.

Zmiany w składzie osobistym duchowieństwa diecezjalnego, „Miesięcznik Pasterski Płocki” II (I9I6) nr 7, s. 22I. 
[...ski], Słówko w kwestii rozgraniczenia parafi, „Miesięcznik Pasterski Płocki” II (I9I6) nr I, s. 30-33.

\section{PRASA}

Bonalska, E., Statuetka Jednorożca 2017 dla księdza, „Głos Gminy Jednorożec” (2018) nr I (49), s. 7 .

Flaczyński, F., Echa przasnyskie, „Kuryer dla Wszystkich” 2 (I9I5) nr I58, s. I.

Piekut J., Z przebytych chwil w Przasnyszu i okolicy (dokończenie), „Kurier Płocki” I (I9I5) nr I29, s. 4 .

Pęski, A., Ziemia Przasnyska, „Kurier Płocki” 2 (І9ı6) nr 67, s. 3.

Piekut, J., Z przebytych chwil w Przasnyszu i okolicy (dokończenie), „Kurier Płocki” I (I9I5) nr I29, s. 4.

Z okolic zniszczonych, „Kurier Płocki” I (I9I5) nr IO4, s. 2.

\section{OPRACOWANIA I ARTYKUŁY NAUKOWE}

Borkowski, A., Eugeniusz Józef Dominik Kłoczowski, w: A. Borkowski, P. Kaszubowski, Przasnyskie portrety. Część druga, Przasnysz-Ciechanów 2008, s. $44-46$.

Chorzępa, J., Przasnysz luty 1915. „Najciekawsza bitwa I wojny światowej”, Przasnysz 2008.

Cierliński, Z., Na północ od Przasnysza: Baranowo, Chorzele, Jednorożec, Przasnysz I996.

Czarnowski, R., Dziedzictwo królowej Bony. Zarys dziejów parafii Chorzele, Chorzele 200I.

Dobroński, A., Walki w rejonie Przasnysza w I wojnie światowej, w: Tradycje niepodległościowe na pótnocnym Mazowszu w XIX i XX wieku. Materiaty z sesji naukowej, Przasnysz, 23 kwiecień 2003, Przasnysz 2003, s. 57-68.

Drwęcki, A., Działalność Polskiej Organizacji Wojskowej w powiecie przasnyskim w latach 1916-1918, „Zeszyty Naukowe Ostrołęckiego Towarzystwa Naukowego" 3 (I989), s. I7-25. 
Drwęcki A., Ruch oporu w gminie Jednorożec 1939-1945, Jednorożec 20 II.

Grzybowski, M. M., Jubileusz 6oo-lecia parafii Krasnosielc 1386-1986, „Studia Płockie" I5 (I987), s. 203-2I4.

Grzybowski, M. M., Kościót katolicki, w: Dzieje Mazowsza, t. 4: Lata 1918-1939, red. J. Szczepański, Pułtusk 2010, s. 6oI-632.

Jezusek, W., Kronika parafialna, „Miesięcznik Pasterski Płocki” 43 [44] (I959) nr I-2, s. 26-28.

Józef Piekut, w: A. Borkowski, Przasnyskie portrety. Część pierwsza, Przasnysz 2004, S. 98-IOI.

Katalog zabytków sztuki w Polsce, z. ı8: Przasnysz i okolice, red. I. Galicka, H. Sygietyńska, oprac. aut. I. Galicka, H. Sygietyńska, wstępną inwentaryzację przeprowadziły A. Bartczakowa, F. Uniechowska, Warszawa ı980.

Kłoczowski, E., Wspomnienia mazowieckiego ziemianina z lat 1897-1951, red. A. K. F. Wołosz, Ciechanów 2006.

Kmoch, M. W., Między idea a rzeczүwistościa. Rady Opiekuńcze na przүkładzie powiatu przasnyskiego (1916-1918), „Bieżuńskie Zeszyty Historyczne” 32 (20I8), s. 64-II6.

Kmoch, M. W., O pierwszym kościele w Jednorożcu $i$ miejscowej filii parafii Chorzele (1862-1915), „Rocznik Przasnyski” 3 (2016), s. 65-II9.

Kmoch, M. W., Organizacje religijno-społeczne w parafii Jednorożec $w$ okresie międzүwojennym, „Rocznik Przasnyski” 5 (2018), s. 25-70.

Kmoch, M. W., Wielka Wojna we wspótczesnym krajobrazie gminy Jednorożec (pow. przasnyski), „Akademickie Zeszyty Naukowe Piast” I (20I7), s. 25-28.

Konstanty Lewandowski 1886-1943, w: M. M. Grzybowski, Duchowieństwo diecezji płockiej, Wiek XX, t. I, cz. I, Płock 2007, s. 3I3-3I4.

Ks. Józef Ciesielski (1878-1944), oprac. Z. Żukowski, w: Kapłani-świadkowie wiary. Biografie wybranych księży zwiąanych z diecezją łomżyńska, red. T. Olszewski, J. Rusiecka, Łomża 20I8, s. 9I-93.

Lewandowski Konstanty ks., w: S. Pajka, Stownik biograficzny Kurpiowszczyzny XX wieku, Kadzidło 2008, s. 588-589. 
Lorenc, Z., I wojna światowa w gminie Jednorożec, Jednorożec 2013.

Łyjak, W. Z., Organy na Mazowszu w diecezji płockiej od 1818 do 1925 roku, Płock 2008.

Odpowiedzi i Informacje, „Miesięcznik Pasterski Płocki” II (I916) nr 8, s. 249.

Parafia św. Mikołaja w Chorzelach 1551-2001, oprac. M. Przytocka przy współudziale Z. Morawskiego, Ostrołęka 2003.

Parzych, A., Ks. Józef Ciesielski 1878-1944-proboszcz $i$ dziekan ostrowski 1925-1944, „Rocznik Ostrowski” 3 (20I7), s. 240-242.

Pokropek, M., Budownictwo drewniane Kurpiów Puszczy Zielonej, Ostrołęka 2016.

Pszczółkowski, A. A., Miasteczka szlacheckie w ziemi ciechanowskiej, w: Działalność społeczno-gospodarcza mazowieckich ziemian w okresie od XVIII do XX wieku, red. B. Umińska, Ciechanów 2014, s. 36-40.

Pszczółkowski, A. A., Źródła do dziejów parafii (Krasno) Sielc. XVI-XVII wiek, „Krasnosielcki Zeszyt Historyczny” I (2010) nr 2, s. 7-9.

Ruszczyk, G., Drewniane kościoły w Polsce 1918-1939. Tradycja i nowoczesność, Warszawa 200I.

Słownik geograficzny Królestwa Polskiego i innych krajów słowiańskich, red. F. Sulimierski, B. Chlebowski, W. Wawelski, t. 3-II, Warszawa I882-I89o.

Świecki, T., Wybult, F., Mazowsze Płockie w czasach Wojny Światowej i powstania Państwa Polskiego, Toruń I932.

Tajchert, A., Koleje waskotorowe na Kurpiach, Rybnik 2015.

Waleszczak, R., Przasnysz i powiat przasnyski w latach 1866-1939. Zarys dziejów, Przasnysz I999.

Wojciechowska, T., Jednorożec. Historia wsi, Jednorożec 2015.

Wojciechowska, T., Ulatowo-Pogorzel, w: Zapiski Ziemi Jednorożeckiej, red. M. Dworniczak i in., Jednorożec 20II, s. 56-6I.

Zniszczenia wojenne w budowlach b. Królestwa Polskiego, oprac. Z. Limanowski, Warszawa I9ı8. 